\title{
THE REPRESENTATION OF TRIANON TRAUMA AS A CHOSEN TRAUMA IN POLITICAL NEWSPAPERS (1920-2010) IN HUNGARY
}

\author{
BARBARA ILG ${ }^{l}$
}

\begin{abstract}
The Treaty of Trianon and its consequences continue to be considered traumatic by both scholars and much of society in general. Trianon's identification as a social or historical trauma not only spread amongst the public in general, but also penetrated historical discourse and journalism. A rather complex and controversial concept has been transposed from psychology to historiography. Hungarian historians generally use trauma in the classical social-psychological meaning: trauma is a social construct based on actual experience (Kovács 2015). In social psychology, the concept of trauma is based on the threat from the outside world to the individual and their identity. However, social trauma has much in common with individual trauma (László 2005). Inevitably, the question arises as to why the concept of psychic trauma seems to be an appropriate scientific description of the effects of Trianon. In my research, I undertook longitudinal content analysis of articles about Trianon and its consequences published in newspapers of various political orientation, divided into five-year periods between 1920 and 2010. The study uses the theoretical construction of social psychology, which involves examining the chosen trauma as a narrative structure. In this study, I present how the concept of the chosen trauma can be applied to describe Trianon trauma through the corpus that includes texts from these ninety years. To illustrate this, I use narrative psychological content analysis.
\end{abstract}

KEYWORDS: chosen trauma, collective trauma, individual trauma, narrative psychological content analysis, Treaty of Trianon, narrative framework

1 Barbara Ilg is a PhD candidate at Corvinus University of Budapest; e-mail: ilgbarbi@gmail.com. This publication is part of the EFOP-3.6.3-VEKOP-16-2017-00007 project entitled 'Young Researcher Talent - Activities Supporting Researchers' Careers in Higher Education.' 


\section{INTRODUCTION}

The Treaty of Trianon that ended World War I was signed at the Grand Trianon Palace in Versailles on June 4, 1920 by the representatives of the Entente Alliance and by Ágoston Benárd and Alfréd Drasche-Lázár, representing the Simonyi-Semadam Government. With the entry into force of the Treaty, Hungary's territory and population decreased by nearly two-thirds, and the ethnic Hungarian population became part of the successor states as a result of the disannexation of those territories. Following the Treaty, Hungarian governments strove for its revision, which was partly accomplished as a result of Hungary's alliance with Germany, which enabled the reannexation of Upper Hungary in 1938, Sub-Carpathia in 1939, and Northern Transylvania in 1940. However, after the end of World War II the Paris Peace Treaty of 1947 restored the Trianon borders. The Treaty and its consequences resulted in collective trauma among Hungarians both in the disannexed territories as well as within Hungary's revised borders, and the Paris Peace Treaties of 1947 repeated the shock.

During the period of socialism in Hungary, little was said about Trianon, which came to the fore again in the public domain after the political changes of 1989, especially regarding the situation of ethnic Hungarians living in former Hungarian territories. In 1990, newly-established democratic parties in Hungary signed a declaration stating that the then-prevailing borders were considered permanent. In 2004, Hungary's accession to the European Union raised the expectations of the Hungarian minorities, only to be followed by the failure of a referendum on dual citizenship in the same year. In 2010, the Hungarian Parliament passed legislation making June 4 the Day of National Unity.

The ongoing awareness of Trianon and its continuing presence in historical narrative by Hungarians as a threat to their identity indicate its recognition as a traumatic event in the nation's collective memory. When a group of forbearers experiences a traumatic event that is passed on from generation to generation in the mental representations of a group as an identity threat, and even becomes a basis of group identity in intergroup conflict, Volkan refers to this as the group's "chosen trauma" (Volkan 1998, 2007).

I undertook a longitudinal analysis of articles on the Treaty of Trianon and its consequences published in newspapers of various political orientation, divided into five-year periods between 1920 and 2010, applying an understanding of chosen trauma as a narrative structure. In this study, I present how the concept of chosen trauma can be applied to describe the Trianon trauma through the corpus that includes texts from these ninety years. To illustrate this, I use narrative psychological content analysis. 
I consider the successive texts through time to be progressive or ascending narratives aimed at a positive goal, the stages of which can be aligned with the symptomatic and healing stages of the chosen trauma. At the end of each section, I postulate narratives corresponding to the trauma codes.

\section{THEORETICAL FRAMEWORK OF THE ANALYSIS}

\section{The concept of chosen trauma}

Volkan's concept of chosen trauma refers to a group's collective memory of a tragedy suffered by their ancestors. Naturally, it is not the group that chooses to become a victim. The word 'chosen' implies that the injured self, inherited through generations and infused with the memory of the trauma of its predecessors, becomes an unconscious element of the wider group's identity. The function of the chosen trauma is to determine the identity of the group according to the trauma of predecessors. The mental representation by the present group of the trauma(s) is much stronger than memories of ancestral glory, as bygone glory does not leave behind unfinished psychological tasks. The tasks given to the new generation confirm their identity with the adults of the previous one. In the development of the chosen trauma, psychological challenges await a solution to end the process of mourning the previous generation, and to avenge shame and humiliation associated with the stored images. The psychological tasks related to the chosen traumas make the same an essential feature of large groups and a powerful engine of social and political movements (Volkan 2007).

Some triggering events cause more traumatic symptoms than others. Natural disasters and unintentional tragedies committed by other human beings are less likely to cause long-lasting trauma than affronts committed deliberately by one group of people against another. A deliberate attack resulting in such a loss of human life may cause members of a group to fear the extinguishment of the group. As a result of such events, the victimized group emerges from the conflict humiliated and deprived of human dignity. Such deliberate attacks often occur among neighboring peoples.

Volkan (1998) makes parallel between individual grief and group grief. As the elaboration of individual mourning is more difficult in the case of a suicide or murder because the former are unprepared for the blow, events which threaten the identity or existence of a group are likewise complicated. Members of groups sharing the same collective loss go through the same psychological process of 
mourning. After the initial shock, the traumatized agent attempts to reverse the loss of the object. Society elaborates it with cultural or religious rituals and then, over the years, repeats the rituals with decreasing intensity, usually on the anniversary of the event. Then collective mourning subsides and society as a whole adjusts to the loss, which will slowly fade away. In the case of other types of tragedies which directly affect a considerable part of the group or cause more lasting damage, such as the killing of a highly respected political leader, commemorative acts recur for several years. Their elaboration may be helped by the erection of a monument, such as the Vietnam Monument, which represented the pain of Americans related to losses in the war condensed into an object.

However, there are situations in which shared grief makes group members feel stupefied, helpless, and humiliated, or too angry to mourn or even to begin the mourning process. In these cases, the members of the group are unable to respond collectively, since these types of losses disrupt the fabric of society and produce traumatic symptoms in members of society. The trauma is then inherited and its elaboration is left for the next generation. Survivors are doomed to pass on the memory of the tragedy and their feelings to descendants so that later generations can elaborate the mourning process that their forbearers were not able to accomplish.

Trauma is transmitted in two ways: by projection, or by alienation - that is, denial. In the course of projection, an older person unconsciously externalizes and projects their traumatized self into the personality of the developing child. The child becomes the gathering point, retaining the worry of previous generation, absorbing their desires and expectations and feeling the urge to work on them, thus the mourning process will become their task (Volkan 1998).

The other manner of coping with the effects of a blow is alienation or denial: those who did not directly experience the tragedy in the group avoid those who were directly affected. For example, after World War II many Israelis looked at the Holocaust with shame and avoided Holocaust survivors. The denial that occurred with Holocaust survivors and their contemporaries also appeared among the victimized generation and their children. Subsequent generations may try to erase the bygone event from their memory, and thus it remains dormant in the psychological DNA of group members for many years.

However, it reappears in some circumstances. Political leaders, for example, can be remarkably successful at awakening the memory of a sleeping group. When the mental representation of the original loss is revived, it can distort the perception of the wider group, and new enemies can be perceived as ones known from the old historical event. Although the original event was undoubtedly humiliating, the function of the mental representation is modified when it is evoked, and it now serves to connect the individual to the group, raising 
members' self-esteem and charging them paradoxically by calling on them to avenge the humiliation of their ancestors.

However, if historical circumstances do not allow the next generation to escape their powerlessness in relation to the past, the mental representation that is retained of the common tragedy serves to hold the members of the group together. Instead of increasing the group's self-esteem, the mental images of the event result in people sharing the powerlessness of victimhood. Consequently, the chosen trauma is not necessarily obvious on the surface of current mental representations of the present group, but it is triggered by certain historic circumstances (or political leaders), most often in the case of identity threats (Volkan 1998).

The chosen trauma is preserved in the collective memory of groups and passed on from generation to generation. Historical memory and personal or group memory are not clearly separable entities in collective memory. Modern historical consciousness is also part of the collective memory, together with personal memory and tradition (Gyáni 2010).

\section{The group trauma model in scientific narrative psychology}

Social psychology discusses the concept of trauma in the context of dealing with a threat to the individual from the outside world and, in conjunction therewith, in the context of identity. At the same time, it shares many features with psychic trauma. The individual is forced to cope with the threat from the outside world, which leaves a mark on their identity. When a coping mode fails, the individual is forced to reconsider and re-construct their identity (László 2005).

The traumatic theory model of scientific narrative psychology juxtaposes collective identity and personal identity - that is, just as we infer an individual's identity state from their personal narrative, group identity states and identity construction processes are derived from group history. Symptoms triggered by a traumatic event affecting either an individual or a group threaten the continuity and stability of identity, and so narratives and stories about the trauma are embedded in the actual life history of the individual or the group. In a parallel way to the elaboration process of individual trauma, the group, like the individual, strives to rebuild its identity that has disintegrated as a result of the traumatic event; that is to say, to create a new identity history acceptable to all members of the group. In this way, group histories provide an insight into not only the current state of injuries to group identity, but also the processes of identity recovery - that is, the trauma elaboration process in collective memory. 
Narratives that deal with the traumas affecting groups are those most suitable for examining the elaboration of collective traumas when there is a consensus within the group that the event did indeed have a traumatic effect. Starting from the psychological model of individual trauma elaboration, the following structural and content-related features in a narrative suggest that a trauma has not been elaborated yet:

(1) re-experiencing of trauma: present-time narration, interjections; (2) strong emotional involvement reflected in a high number of emotional expressions: explicit emotions, emotional evaluations and extreme words instead of cognitive words; (3) regressive functioning: primitive defense mechanisms, such as denial, splitting (devaluation and idealization) in extreme evaluations, distortion through biased perception and a self-serving interpretation of events, projection of negative intentions and feelings in hostile enemy representations (hostile emotion attribution); (4) narrow perceptual field: inability to change perspectives; (5) paralysis: perseverance of cognitive and emotional patterns; (6) a sense of losing agency and control: transmission of causal focus and responsibility to others; (7) polemic representations instead of hegemonic representations; (8) intense occupation with the topic in social discourse, a pressing need to share the topic with others and a constant flow of trauma-related narratives (Fülöp et al. 2012).

In contrast, the narrative of elaborated trauma conveys a positive identity that is coherent with the whole of group history and accepted by everyone within the group. It contributes to the maintenance of a positive national identity, and represents the event as part of the past, which has no effect on present-day relations in relation to the groups concerned (Csertö-László 2016).

From a narrative psychological perspective, the trauma affecting the group can be examined if it is the result of intergroup conflict (war, genocide, etc.) since the narratives of the trauma in this case are narratives of an intergroup conflict in which the participants, according to the dialectic of trauma, are as follows: victims and perpetrators - that is, clearly identifiable participants. Narrative psychology relies on classical intergroup research (intergroup agency, intergroup evaluation, intergroup emotions), and so derives the state of trauma elaboration from the narrative representation of the relationship of the groups involved in the conflict to one another and the event.

Narrative psychology has developed the method of narrative psychological content analysis for analyzing texts, which is a computer-based quantitative content analysis methodology that looks for psychologically measurable linguistic features of narrative composition and narrative categories. The Content Analysis Suite called NarrCat has a variety of dictionaries which contain words which are relevant to personal or group identity, together with grammatical structures which also transmit information about the individual 
or group identity states beyond the semantic meaning of the words (László 2012). These dictionaries are organized into various modules, which have been developed within the framework of the computer software called NOOJ and are suitable for identifying the linguistic markers of psychological content and measuring their frequency automatically.

\section{Conceptualizing Trianon trauma as chosen trauma}

There is a clear correspondence between Volkan's concept of chosen trauma and the pattern of psychic trauma, the major elements of which are as follows: the unexpectedness and severity of a traumatic event - that is, the fact that it breaks the identity or the 'fabric of society.' Additionally, the dichotomy between the victim and perpetrator (that is, between 'good' and 'bad'), which offers the opportunity to identify oneself with the victim or the witness, and the emergence of the traumatic syndrome in the form of bursts of memory and narrowing down, and finally the stages of healing, such as resistance, projection, interpretation and reworking. Trauma implies doubts and anxieties about incompleteness, thus in normal cases the national group seeks to eliminate these.

I consider the Trianon trauma to be the chosen trauma of the Hungarian national group, since it appears in the group's collective representations of the past as an identity threat, and is therefore suitable as the basis for group identity when called upon. The use of the word "trauma" in the case of the Treaty of Trianon legitimizes the incompleteness of the story and the unprocessed nature of the trauma, so that it can be retrieved time and again as an unsolved task. Imagining the Treaty of Trianon and its consequences as a trauma suggests hope for healing, a positive conclusion to the story, while it also exempts victims from responsibility.

The framework of the chosen trauma (similarly to with individual trauma) is in fact the same narrative structure, from the occurrence of the traumatic event through the symptoms to healing - however, without aiming at closure. Accordingly, resolving individual and collective trauma is in itself a progressive narrative which aims at restoring the positive identity of a person or group. The narrative structure of trauma consists of invariable elements - these are the triggering event, the symptomatic stages, and the healing stages. Each phase is also accompanied by a narrative with a constant pattern, which also provides information about the state of the elaboration. For example, a disaster narrative arises when a triggering event occurs, a denial narrative in the denial phase, and a scapegoat narrative in the projection phase. Thus, the constant elements of the narrative structure indicate which traumatic narrative typical of which stage of 
the trauma is currently in circulation in the mental representations of the group. However, even though the structure of the chosen trauma is the same as that of the collective trauma, the chosen trauma is a victim's narrative, the purpose of which is to prevent trauma elaboration, which is why it can repeatedly be encountered in the life of the group.

The mental representations of Trianon trauma in collective memory can be organized into the narrative structure of the trauma from the time of the treaty to the present day. Trianon trauma representations which have developed over time during the past one hundred years are imprints of the elaboration process of the Hungarians, through which, according to my assumption, the group is progressing towards trauma elaboration over time.

The stories of Trianon trauma are passed on in collective memory and are manifested in personal narratives, historiography, and the media. Both the narrative patterns of each phase and the current state of trauma elaboration can be described by means of the longitudinal cross-sectional study of the narratives of Trianon trauma. Narratives of such trauma can be texts about the chosen trauma of the group in historiography or in the media, since the chosen trauma begins with a triggering event that occurs in the canonical history of the group and reoccurs as the story of the group is told. To explore the structure of the trauma, I have chosen the method of psychological content analysis, since this uses language modules that can provide relevant information about the state of trauma, in parallel with the emergence of traumatic symptoms and phases of the healing process.

\section{RESEARCH}

For the purpose of exploring the longitudinal structure of narratives and the states of trauma, I examined texts that appeared in the media since the First World War. The printed press has played an important role in the formation of collective memory and in the discussion of collective trauma. On the other hand, the media present the views of different political and social interest groups according to the conditions of democratic publicity (Habermas 1993).

From 1920 to 2010, broken down into periods of five years, I analyzed articles that discussed the Treaty of Trianon in five or six newspapers with differing political orientations. I assumed that the topic had been on the agenda of the media since June 4, 1920, and has been recalled on anniversaries, so I searched for items published in the interval preceding and following June 4 by one week - that is, between May 25 and June 11 . 


\section{HYPOTHESIS}

\section{Hypotheses for the entire text corpus}

H1: My assumption is that, applying the structural elements of the ninetyyear trauma narrative to the whole text corpus, the trauma representation appertaining to the entire Hungarian group organized in the period between 1920 and 2010 is as follows:

(1) Signing of the peace treaty: sudden shock; (2) 1930. Memorial services, re-emergence of the trauma: anger, denial, resistance, revenge, demanding reparations. The loss becomes a traumatic event upon the effect of revisionist propaganda; (3) 1935. Successful foreign policy: demanding legitimate reparation; (4) 1940. Area reannexations: Legitimate expectations are fulfilled; (5) 1947. Paris Peace Treaty: retraumatization (no data are available about this); (6) 1945-1990 no news: a period of suppression, latency; (7) 1990-2010. Trauma narratives that serve for the restoration of identity and healing.

H2: In the course of the longitudinal study of right-wing and left-wing newspapers, the extent of the trauma elaboration as well as the trauma narrative of right-wing and left-wing groups will also be different.

\section{Hypotheses about the correlation between narrative psychological language markers and trauma elaboration in texts}

Narrative psychology builds on classical social psychological intergroup studies, so collective trauma is actually seen as the result of group identity damage in an intergroup conflict. Examining the trauma elaboration process in the group, we may distinguish in the texts conflict between cognitive and emotional content attributed to ingroups and to outgroups. However, it is an important stipulation that trauma is considered to affect one's own ingroup, and it is one's ingroup that endows itself and the outgroup with cognitive and emotional content. Although in intergroup conflict the ingroup and the outgroup appear as single groups, it should not be forgotten that large national groups consist of smaller groups and individuals.

Using the research method of narrative psychology, we may filter out the linguistic features of mental content attributed to groups involved in conflict from the text, and construct hypothesis about trauma processing. That is, we look for correlations between the frequency of language markers and the 
narrative representations of trauma that appear in the text. Such language traits manifest intergroup emotions and intergroup evaluations.

In my own research, I examined what kind of trauma narratives with which psychological traits were in circulation at the time of the traumatic event -i.e., the signing of the Treaty of Trianon - until 2010.

Regarding the correlation between trauma elaboration and narrative psychological linguistic content in the texts, I define the following hypotheses:

H3: The ingroup and the outgroup both consist of smaller groups: the narrator of the texts, who is a member of the ingroup, attributes the mental content to the large group, smaller groups, and individuals. These groups may vary from year to year and from newspaper to newspaper.

H4: Ideally, the progress of time will be the most important factor in relation to the trauma elaboration.

H5: According to my hypotheses, the correlation between the intergroup evaluation and trauma elaboration is the following:

An unelaborated trauma is defined when there is a sharp difference in the evaluation of the ingroup and the outgroup; and the ingroup assessment is characterized by positive while that of the outgroup by negative bias. In the case of the ingroup, this pattern implies shifting the responsibility to the outgroup, and implies a narrative in which the ingroup insists upon restitution, since the responsibility for the negative event is borne by the negatively evaluated group. The progress of trauma elaboration is indicated by the fact that both the positive evaluation of the ingroup and the negative assessment of an outgroup also decrease (thus responsibility is divided, and the role of the ingroup will be emphasized in the narrative of the negative event).

H6: In the period immediately following the traumatic event, both in the ingroup and outgroup, the traumatic event narrative has strong emotional saturation and little cognition. High emotional involvement entails the use of numerous emotional terms: these include explicit emotions, emotional evaluation, and the use of strong emotional words compared to cognitive expressions.

H7: Early narratives will show a regressive mode of action: to include primitive countermeasures, such as denial and the projection of negative intentions and feelings.

H8: I assume the following relationship between the relative frequency of collective emotions and the linguistic forms of denial and the trauma elaboration process: in the first stage of trauma elaboration, the number of these indicators will be high, but will decrease simultaneously with the trauma elaboration process over time. 


\section{METHODOLOGY}

\section{Test sample: selection of newspapers}

I examined newspaper articles about the Treaty of Trianon that were published within a period of one week before June 4 and one week after.

The first consideration in selecting the newspapers was the continuous publication of the newspaper over the ninety years under review. If this was not the case, then I selected the successor newspaper or a similar newspaper along the same political lines. In 1920, papers still reflected a broad political scale, ranging from extreme right-wing opposition pages through liberal newspapers to leftist radical ones, but by the late twenties they had shifted to the right. In December 1944, all Budapest newspapers were banned, and in February 1945 only Népszava was restarted. Between 1945 and 1990, the media served the single-party system, and after the political system change the press was mostly bipartisan, rather than becoming independent (Buzinkay 2016). Therefore, the political orientation of the newspapers selected for research can best be determined by the categories of political left wing and right wing in the text corpus that spans 90 years.

However, to select the contemporary dailies (published in 1920) and to identify policy orientations, I had to consider the following historical aspects:

Between 1867 and 1918 Hungarian journalism was strongly characterized by party-biased journalism, meaning that contemporary newspapers reflected the views of a given political party, organization, or political trend. 'The period from 1848 to 1918 was the era of national liberalism" in Hungary, and this ideology determined public policy after the AustroHungarian Compromise of 1867 . The constitutional monarchy created by the compromise provided an opportunity for parliamentary development based on the principle of popular representation' (Körösényi et al. 2007:18). The vast majority of the Hungarian press can be identified on the scale as liberal before the First World War. However, from the outbreak of World War I war censorship came into effect, which also involved the censorship of newspapers and the periodical press, and control of correspondence between the front and the hinterland. As a result of Hungary's defeat in the war,

2 National-liberalism: In Europe, for much of the nineteenth century, liberalism was the ideology, and the Liberal Party was the force that defended constitutionality against absolutism and developed the agenda for a modern, progressive, civilized European middle-class society. To this end, its main goal was to create an independent and strong nation state. Later, at the turn of the century and between the two world wars, liberalism and nationalism separated (Dénes 2008:5). 
revolution broke out in Budapest on October 30-31, 1918, which led to its withdrawal from the Austro-Hungarian Monarchy and Hungary becoming a republic. The new government was forced to maintain the newsprint-related restrictions introduced at the beginning of the war, but in a law of December 7, 1918, it restored press freedom - that is, it abolished war censorship, and introduced newspaper street sales. Shortly afterwards, the communist council government, which came to power on March 21, 1919, enshrined press control and the nationalization of press life in the constitution. A few days after the proclamation of the Council Republic, the elimination of newspapers began, and by June 1919 there were only five daily newspapers in Budapest and 25 in the countryside, almost all of which operated as newspapers of the Communist Party (Buzinkay 2016). After the overthrow of the Hungarian Council Republic, a counter-revolution against the communist revolution came to power and the surviving papers were republished on September 28, 1918 based on prior permission and the amount of paper allocated to them. Between the fall of 1919 and 1922, each of the new power groups regarded the liberal press as an enemy. The liberal press as the cause of the loss of the war, the enemy of national aspirations, and even of the loss of historical Hungary, appeared in counter-revolutionary discourse. The incumbent powers exercised their right to censorship and classified liberal newspapers as destructive and partly problematic. The latter were opposed by the Christian-national 'reliable' press. The products of the Christian national press were newspapers founded after 1918 (Buzinkay 2016).

In the period between 1920 and 1944, I examined seven political dailies. ${ }^{3}$ Three of them were founded in the late 1800 s during the era of national liberalism: the first in chronological order was Népszava (1873-), the newspaper of the Hungarian Social Democratic Party, founded in 1873. The second was the national-liberal Pesti Hirlap (1878-1944), founded in 1878, and the third high-volume daily was the conservative-liberal Budapesti Hirlap (1881-1933). I chose two of the dailies published after the turn of the century but before the First World War: the civil-liberal Az Est (1901-1939) and the civil-radical Világ (1910-1926), which under the civil government was a pro-government newspaper. Among the Christian-national newspapers founded after 1918, I included the radical right-wing Új Nemzedék (1919-1944) and Magyarság (1920-1944) in 1930 (Világ ceased to exist in 1926, so it was replaced with the Magyarság). ${ }^{4}$

3 The political classification of the newspapers was based on the studies of Sipos (2011a), Klestenitz (2013) and Litván (1984).

4 The seven dailies are presented in the Appendix. 
However, in 1925 the peace treaty was not on the agenda for the two weeks under examination. A completely different issue dominated the columns of the newspapers: On May 31, 1925, the newspaper Újság published a report on the confession of Ödön Beniczky, former Minister of the Interior about the Somogyi-Bacsó murder, in which he called the Regent (Horthy) an instigator. Therefore, in 1925, during the two-week period, I did not find any newspaper articles about the Treaty of Trianon in the seven dailies.

The treaty was mentioned in all six newspapers involved in the study in 1930, while only in four in 1935, and only in the editorial of Pesti Hirlap published on June 4 in 1940. As for 1945, I was unable to create a corpus of texts because the newspapers involved in the research were abolished by the decree dated December 15, 1944. Although Népszava resumed on February 2, 1945, it did not publish any articles about Trianon around the anniversary. After 1945, I examined three newspapers which continued to exist even after 1990 that could be located on the political left and right wing after the political system change. These are Népszava (1873-2019), Szabad Nép, published in 1944, the legal successor of which was Népszabadság, published in 1956 (1944-2016), and Magyar Nemzet (1938-2018). After 1945, the media were aligned with political powers - for example, Népszabadság was the organ of the Hungarian Socialist Workers' Party, and Trianon was a silenced topic. Accordingly, no pieces were published in the three daily newspapers around the anniversary between 1945 and 1990. However, after the political system change, all three newspapers kept the issue of Trianon on the agenda in all five years studied during the period under review.

I formed nine corpuses of texts from the collected newspaper articles, one for each year, and conducted a political media-agenda settings analysis (Török 2005) to explore the main issues and events that occurred in the examined two weeks.

\section{Grouping the texts according to the hypotheses}

At first I formed nine text corpora from the newspaper texts (1920, 1930, 1935, $1940,1990,1995,2000,2005$, and 2010), thus in the course of the longitudinal study I revealed the structure of the trauma narrative of the chosen trauma of the Hungarian group, and made findings about the trauma elaboration processes. The right-wing and left-wing classification of the newspapers also made it possible to examine the trauma representations of the right-wing and left-wing groups throughout the sample; accordingly, I compiled a right-wing text corpus and a left-wing text corpus. 
Table 1 comprises the newspapers classified as right-wing or left-wing newspapers broken down into years.

Table 1. Composition of text corpuses formed according to newspapers and their political orientation between 1920 and 2010

\begin{tabular}{cccccc}
\hline & 1920 & 1930 & 1935 & 1940 & $1990-2010$ \\
\hline Right-wing & Budapesti Hirlap & Budapesti & Budapesti & Pesti & Magyar \\
& $(1883-1939)$ & Hirlap, & Hírlap, & Hirlap & Nemzet \\
& Pesti Hirlap & Pesti Hirlap, & Pesti Hirlap, & & $(1938-2018)$ \\
& $(1841-1944)$ & Új Nemzedék, & Magyarság & & \\
& Új Nemzedék & Magyarság & & & \\
& $(1919-1944)$ & $(1920-1944)$ & & & Népszava, \\
\hline Left-wing & Népszava $(1873-)$ & Népszava, & Népszava & & Népszabadság \\
& Világ & Az Est & & & $(1944-2016)$ \\
& $(1911-1949)$ & & & & \\
& Az Est & & & & \\
& $(1914-1939)$ & & & &
\end{tabular}

Source: Author's compilation

Grouping the texts by year provides an opportunity to examine the first hypothesis - i.e., what the dominant trauma narrative is in a given year from the perspective of the ingroup. The current trauma narratives are determined by the topics kept on the agenda in the two-week period in each text corpus. The victim and perpetrator groups can also be identified in the trauma histories of the text corpora, starting from the dialectic of the chosen trauma.

The left and right divisions of the nine text corpora provide an opportunity to test the second hypothesis: i.e., to outline the trauma narrative of the politically leftand right-wing groups within their own groups, highlighting possible differences.

However, to determine who belonged to the right-wing and left-wing group, and to the whole nation and the outgroup, and what mental content these groups were endowed with, I grouped the texts by year and newspaper, and created a total of 32 corpora.

\section{Method for screening dominant groups: word frequency analysis}

In the narrative of Trianon trauma (from the point of view of the Hungarian group), the Hungarian nation as a whole is the victim, and the perpetrators are members of the Entente and nations neighboring Hungary - mainly Romanians and Slovaks, Czechs, Serbs, Croats, and Slovenes. In newspaper articles, at first 
the national groups appear as a whole (for example: Hungarians, the nation, Hungary, people, Slovaks, etc.). However, both the ingroup and the outgroup consist of smaller groups and individual actors. To screen out the dominant groups and actors, I performed word frequency analysis from each text corpus. Then, from each of the most common words per corpus I selected words referring to the ingroup and the outgroups and their subgroups, and counted them. Words of at least three letters, occurring at least five times that referred to ingroup or the outgroup were included in the glossary denoted as agents.

\section{The examination of intergroup evaluation}

I ran the NarrCat computer program evaluation module on the 32 text corpuses, which binds the keywords to their word classes and evaluation marks, then sorts them in a separate dictionary. The modules of NarrCat run in the languagetechnology system of Nooj, which allows the analysis of morphological and syntactical texts in different languages.

Table 2. Dictionaries of the NarrCat evaluation module

\begin{tabular}{llllll}
\hline Word class & & Positive & Pcs. & Negative & Pcs. \\
\hline Adjective & wise & 317 & undue & 582 \\
\hline Verb & & $\begin{array}{l}\text { to brave, } \\
\text { to cheer }\end{array}$ & 122 & $\begin{array}{l}\text { to exploit, } \\
\text { to protest }\end{array}$ & 317 \\
\hline Noun & from an adjective & wisdom & 317 & injustice & 582 \\
& from a verb & cheering & 122 & protestation & 317 \\
\hline Adverb & from an adjective & wisely & 317 & unduly & 582 \\
& from a verb & cheering & 122 & protesting & 317 \\
\hline
\end{tabular}

Source: Bigazzi et al. (2006)

The evaluation keywords, considering their word class, can be adjectives, verbs, or adverbs. The lexicons of verbs and adjectives were compiled by the narrative psychological research group using the digital lexicons of the Hungarian Academy of Sciences Institute of Linguistic Science by frequency of use (Bigazzi et al. 2006).

The evaluation module is at the moment capable of recognizing evaluative and conjugated keywords in texts, and identifying separable verbs and adverbs from verbs. For the identification of references of evaluations (i.e. who evaluates 
whom), and the classification of emotional-cognitive content, the use of software-supported manual analysis is required.

I ran the evaluation module on the texts, grouped by newspaper and year specification, in the Nooj computer analysis program, which provides its findings with their close context (the 3-4 words before and after the word), and also assigns them their valence value. As it is hard to determine the reference subjects of the evaluations this way (because it is not certain that the subject of the predicate is in the highlighted context, or its object), I determined the subject of the evaluation based on the context of the found word.

Using the results of the word frequency test, I reversed the order of the research and examined, in the context of the words denoting the most common agents, whether there were evaluative words or phrase relative to the agent. After that, I checked in the context of the words referencing these groups for positive or negative evaluations of the respective group.

The subjects of the evaluation 'Hungarians' were put into the Hungarian category labelled 'the nation as a whole,' including Hungarians living in the disannexed areas, the political organizations within the nation, associations, the political elite (government, the National Assembly or the House) and political party groups and political actors. In the texts, the composition of the ingroup varies based on the period under analysis. Similarly, the composition of outgroup is made up of smaller groups - basically, the nations, ethnicities, and their representative political parties and figures that were either allied with or against Hungary in the First and Second World Wars.

\section{The narrative perspective of the ingroup according to political orientation}

I differentiated the Hungarian group along political lines, so I assigned a political group, party, or line for every political daily newspaper of its time, and I assumed that specific political daily newspapers represented the evaluations of the group. These political orientations were then evaluated as right-wing and left-wing. In the case of daily newsletters with different political orientations, the narrator and the group's perspective are biased in terms of both the ingroup and the outgroup in terms of political group membership.

I studied ingroup evaluations from the perspective of political orientation in all the 32 sub-corpuses.

I subjected the ingroup evaluations from the perspective of political orientation to a longitudinal study so I could draw conclusions about the processes of recovering from trauma of the left and right. 


\section{Examining the relative frequency of emotions}

I examined the full frequency of emotions attributed to ingroup and outgroup and narrator in chronological order, as well as the emotions attributed to the ingroup and outgroup and the narrator in the newspapers of the right and left.

Automated examination of the texts from the perspective of emotions was carried out by Éva Fülöp with the help of the NarrCat computer program and its emotion module. The emotion graph was developed in 2006 by Éva Fülöp and János László.

The words in the dictionary of the emotion module were selected from the words in the Hungarian Interpretative Dictionary. A total of 700 words were added to the dictionary. The words of the emotion dictionary are descriptive emotional markers that refer to emotional processes and states, such as anger, joy, etc. (Fülöp 2010). The emotion words in the module are organized into separate categories: positive and negative emotions, depressive emotions, moral emotions, and historical emotions.

The relative frequency of emotions in the right-wing newspapers and the leftwing newspapers is presented as a percentage in my own study.

\section{The relative frequency of negation}

Study of the relative frequency of negation was done with the negation graph of the Nooj language system (Hargitai et al. 2005).

Negation can be explicit or open. Negation words include 'no,' 'none,' 'non-,' 'un-' (in Hungarian: nincs, sincs, nem, ne) or 'denial pronouns:' 'nobody,' 'nothing' (senki, semmi, sehány) adverbs: 'nowhere,' 'never' (sehol, soha). Denial can also be implicit or hidden in the Hungarian language using privative suffixes like -tlan, -tlen, -talan, -telen, etc. (suggesting negation, a lack of something or without something).

In my own research I constructed an extreme emotion graph and a negation graph on 32 sub-corpuses, then showed the relative frequency of negation in the right-wing and left-wing newspapers. 


\section{RESULTS OF THE NARRATIVE PSYCHOLOGICAL ANALYSIS}

\section{Results of the intergroup evaluation in 1920}

Hypothesis 5, concerning the validity of intergroup evaluations, was that after the occurrence of the traumatic event the narrative psychological characteristics of the strong shock in the texts of the 1920s would be positive for the ingroup and negative for the outgroup from the perspective of intergroup evaluation. I present the negative and positive evaluations of the intergroup as a percentage of the total number of words in each newspaper (I divided the number of negative and positive evaluations by the number of word corpora grouped by year and daily and multiplied this by a hundred). The results of the 1920 text corpus are illustrated in Figure 1.

Figure 1. Ingroup's evaluations as a percentage, 1920, evaluator: Hungarians (\%)

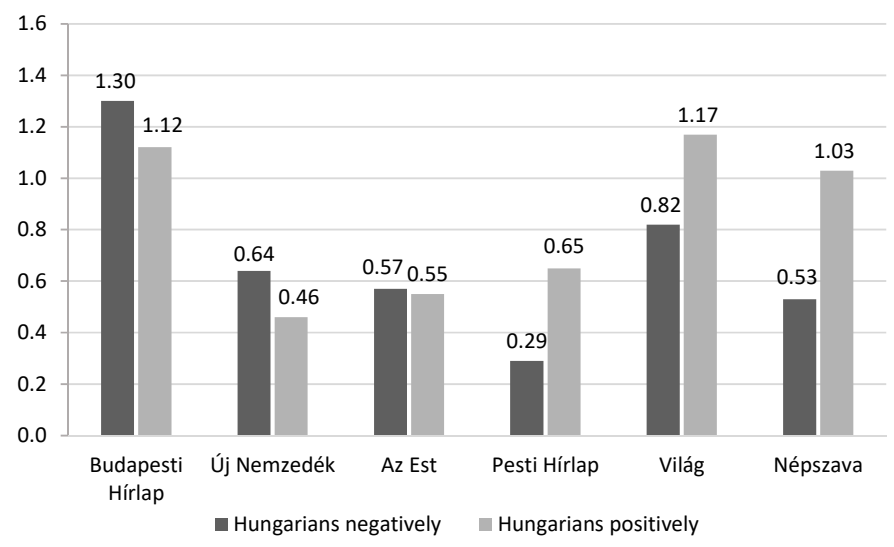

Source: Author's construction

The positive evaluations of the ingroup are almost as numerous as the negative evaluations of the Hungarian group in terms of the distribution of the intergroup evaluations according to valence. Moreover, two newspapers included more negative evaluations of the Hungarian group than positive ones. The reason for this is that Budapesti Hirlap and Új Nemzedék negatively evaluated the government and the national assembly within the ingroup strikingly often, and 
since these evaluations formed one set with the evaluations for the Hungarian group, the number of negative evaluations for the whole group also increased.

This result suggests that the government and the national assembly are hostile groups for the members of the political groups represented in these two newspapers. This is explained by the conflict between the government and the parties as to whether the government should sign the treaty. In contrast, the word government is most often mentioned in a positive context in the text of Pesti Hirlap. On the other hand, the newspaper Világ reports in detail on the demonstration of Transylvanian refugees. The positive evaluations of the refugee group push the evaluation of the Hungarian group into the positive in this newspaper. However, during the examination of Népszava, a separate group emerged within the Hungarian group - namely, a group of social democrats. This group is considered the own group or ingroup in the texts of Népszava, and is always evaluated positively. As I defined the social democrats as part of the Hungarian group, the ingroup evaluation in Népszava is distorted in a positive direction in the text corpus from the 1920s.

Another result of the intergroup evaluation in the corpus of 1920s is that there are more negative evaluations of the outgroup than positive evaluations. The positive and negative evaluations for the outgroup are shown in Figure 2.

Figure 2. Outgroup's evaluations as a percentage, 1920, evaluator: Hungarians (\%)

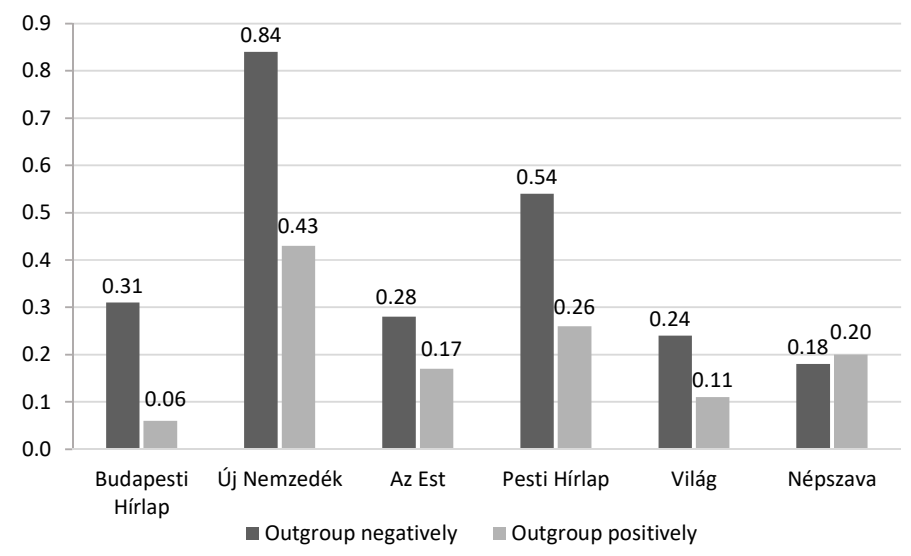

Source: Author's construction

In five of the six newspapers included in the study, the proportion of negative evaluations of the outgroup is much higher than positive ones. Only in Népszava 
is there a little more positive evaluation than negative. Overall, the occurrence of outgroup evaluations is very low in all of the newspapers in the 1920s, at between $0.3 \%$ and $1.3 \%$. The most frequently evaluated group is the Entente the most important topic in the examined period is the signing of the treaty, in which the Entente is deemed the main enemy. The Entente, without exception, receives negative evaluations, as do the French and English. In Új Nemzedék, the negative evaluations of the outgroup are outstanding. On the one hand, this is because only this newspaper reports in detail about the visit of the English workers' delegation, who came to investigate the atrocities of the counterrevolution (white terror) in Budapest. On the other hand, in Új Nemzedék the Czechs, Romanians, and Serbs are portrayed as the greatest enemies, as their aspirations for independence from Hungarians were fulfilled. The Germans, Slovaks, and Vendis in Hungary are sympathetic groups because they do not want to break away from the motherland. Romanians, Czechs, and Serbs are also negative characters in other dailies, except in Népszava. The positive outgroups in the 1920's text corpus are also Germany and the League of Nations.

In summary, in the 1920 corpus, the positive evaluations of the ingroup are relatively strong, and the negative evaluations of the outgroup are more plentiful than the positive evaluations. Immediately after the traumatic event, both values should be extremely high according to the hypothesis - this pattern would refer to the emotional shock suffered by the group.

\section{Results of intergroup evaluation 1930-2010}

In 1930, however, during the examination of the intergroup evaluations, the Hungarian group receives a strikingly high positive evaluation, as we can see in Figure 3.

This result is explained by the fact that 'Hungarians worldwide' support the revision. Hungarians worldwide include the parties in Hungary, the Hungarians beyond the borders, and the Hungarian friendship societies which were created in the great cities of the Western Great Powers due to Revisionist League propaganda. The secretaries of the associations were in direct contact with the Budapest headquarters and provided members with the latest propaganda publications. Such societies also operated in London, Milan, Paris, Amsterdam, Geneva, Berlin, Warsaw, South America, and New York (Zeidler 2009).

At the same time, the evaluations for the outgroup are surprising: namely, the positive evaluations for the outgroups are twice as plentiful as the negative evaluations. This result is possible because only a single hostile outgroup appears in the texts, this being the Czechs; all the other outgroups referred to in the texts 
are national groups who support the Hungarian revision of the peace treaty. The most positive evaluations are of the Italians, followed by the English (because of the 'Justice for Hungary' campaign of Lord Rothermere) and the Dutch, as these countries have the most active associations. This relates to the editors' agendaspecifying function and the effectiveness of revisionist propaganda. Indeed, in the examined period in 1930, the central theme of the dailies was the assemblies and demonstration organized for the tenth anniversary of the Treaty of Trianon; that is, the replaying of the events of 1920 and a pro-revision demonstration. This was supported not only by Hungarians in post-Trianon Hungary, but also by Hungarians living abroad, including in Western Europe, and even in those countries that were formerly their enemies.

Figure 3. Ingroup's evaluations as a percentage, 1930, subject evaluator: Hungarians (\%)

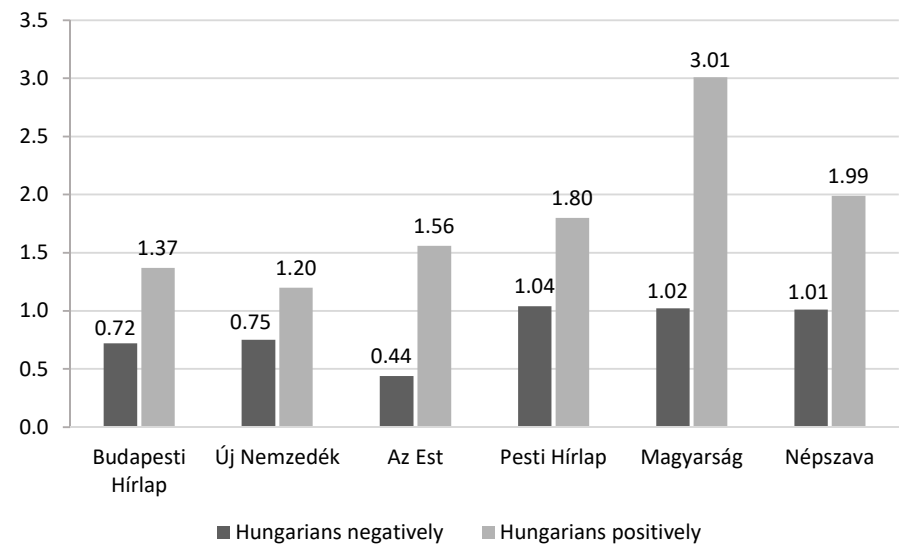

Source: Author's construction

Thus, the two indicators, the values of which according to the fifth hypothesis should decrease in parallel with time, do not decrease, but the positive evaluations of both the ingroup and the outgroup increase in comparison to 1920, while the negative evaluations decrease. From the point of view of trauma processing, this suggests that the self-assessment of the ingroup is positive, and that the group has grown stronger. The evaluation of the ingroup strengthened not because it took responsibility for its past action, but because it was preparing for revenge. This occurs when the ingroup revives the chosen trauma.

In 1935, the positive evaluations for the Hungarian group are slightly less numerous than negative ones; conversely, the negative evaluations of the 
outgroup are exceptionally high. Such extreme evaluations indicate that elaboration was not underway.

In 1940, a single newspaper, Pesti Hirlap, remained on the right wing, and both evaluations of the ingroup and outgroup were positive. The outgroups here are the allied German and Italian groups who helped with achieving the objective; i.e. territorial revision.

In the 1990-2010 corpus, the negative evaluations of the Hungarian group are clearly more numerous than the positive evaluations of the Hungarian group in each year. The negative evaluations of the ingroup point towards emotional elaboration in terms of trauma elaboration if they are equivalent to the positive evaluations, and the negative and positive evaluations of the outgroup are also at a low level. However, in my own survey, the raw frequency of negative evaluations for the Hungarian group was much greater than the number of positive evaluations in all five-year periods surveyed. Likewise, the number of negative evaluations for the outgroup is also high. A plausible explanation for the high number of negative evaluations for both groups from the perspective of trauma elaboration may be the fact that the ingroup attributes the same responsibility for intergroup conflict to itself and the outgroup alike, indicating trauma elaboration has begun.

\section{Intergroup evaluation in right-wing newspapers, 1920-2010}

Negative evaluations attributed to the Hungarian group are not due to the fact that the group has faced the past and holds itself responsible for grievances. In the text corpus of 1990-2010 it becomes obvious that there are opposing groups within the Hungarian group that can be clearly classified as right wing and left wing (the right-wing daily newspaper in the period 1990-2010 is Magyar Nemzet; the left-wing daily newspapers are Népszava and Népszabadság). The Trianon anniversary is juxtaposed by both sides with current political events, which may be commemoration or a political act linked to the treaty. Such events present an opportunity to view the opposing side negatively. For example, when the right-wing evaluates the Hungarian group, it actually evaluates not only itself but also the actors of the left wing, mostly negatively. Thus, these negative evaluations increase the number of negative evaluations of the entire Hungarian group. It can be clearly seen in Figure 4 that the Hungarian group received at least twice as many negative evaluations as positive ones in the right-wing newspapers since 1990. This trend also applies to outgroup evaluation since 1990 (see Figure 5). 
Figure 4. Right-wing evaluation, 1920-2010, subject of evaluation: Hungarians (\%)

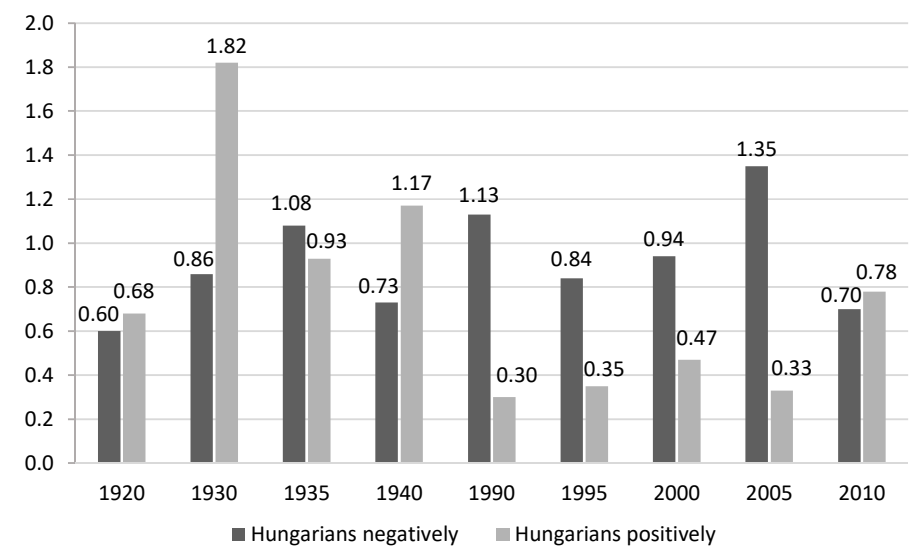

Source: Author's construction

Figure 5. Right-wing evaluation, 1920-2010, subject of evaluation: outgroup (\%)

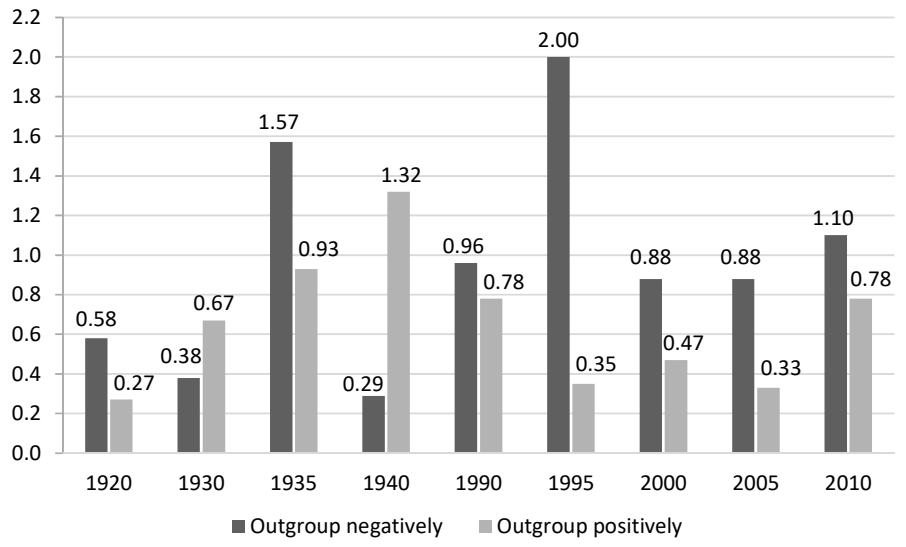

Source: Author's construction

Since 1990, the only representative of the right-wing text corpus was the Magyar Nemzet. Through the texts of the Magyar Nemzet from 1990-2010 I present how the commemorations, the defining of the media agenda, and the political orientation of the newspaper influence intergroup evaluation. I also point to those ingroups and outgroups that were negatively evaluated. 
After the change of political system in Hungary, the right-wing government indirectly privatized Magyar Nemzet by supporting the conservative French group Hersant at the time of purchase. The incumbent MDF believed that extraordinary media support was due to the new system. Important topics in the paper included national affairs and the Hungarian minority in the disannexed territories. While in 1990 the paper was still publishing the articles of left-wing historians such as Mária Ormos (1930-2019) and Magda Ádám (1925-2017), in 1991 the tone of the paper became more exclusionary and judgmental under the influence of right-wing Hungarian writer, journalist, and politician István Csurka, ${ }^{5}$ and in 1991 eight left-wing journalists were fired from the paper.

According to the assessment of these historians, the following processes led to the unfavorable treaty: Hungary's repressive ethnic policy, and consequently the dissatisfaction of other ethnic groups living there; the irredentist aspirations of the new states on the southern and eastern borders (Italy, Serbia, and Romania); and the strategic considerations of the Entente aimed at avoiding German influence in Central Europe. This was compounded by the chaotic political situation in Hungary and the erroneous activities of the peace delegation (Romsics 2001). The authors expressed these arguments in newspaper articles, giving negative evaluations of both the Hungarian group and the outgroup. Within the Hungarian group there are a few actors and events perceived negatively: these are the right-wing and revisionist propagandists, Hungarian public opinion, and the revolutions in 1918-19. Among Hungarian politicians, Albert Apponyi ${ }^{6}$ is evaluated negatively while the negative actors in the outgroup are the Entente, Romania, Czechoslovakia, Wilson, ${ }^{7}$ Clemenceau, ${ }^{8}$ Beneš, ${ }^{9}$ and Masaryk. ${ }^{10}$

5 István Csurka (1934-2012): playwright, right-wing politician. After the change of regime, he was one of the founding members of a party called the Hungarian Democratic Forum. In 1993, he was expelled from the MDF and founded the Magyar Igazság és Élet Party, of which he was president until his death. Parliamentarian 1990-1994 and 1998-2002.

6 Albert Apponyi (1846-1933): conservative-liberal politician, Minister of Religion and Public Education 1917-1918. Head of the peace delegation in 1920. Member of Parliament for Jászberény.

7 Thomas Woodrow Wilson (1856-1924): President of the United States (1913-1921) and creator of the 14 points, which included validation of self-determination for the small Central European states.

8 Georges Benjamin Clemenceau (1841-1929): French politician, 40th and 53rd Prime Minister of the Third Republic. At the end of the First World War, he was one of the founders of the Treaty of Versailles - and the Treaty of Trianon, which divided Hungary.

9 Edvard Beneš (1884-1948): Czech politician, founder and second Prime Minister of Czechoslovakia. His operations contributed greatly to the negative perception of Hungary and the loss of territory defined in the Treaty of Trianon.

10 Tomáš Garrigue Masaryk (1850-1937): First President of the Czechoslovak Republic (19181935). 
In 1995, Magyar Nemzet became state-owned indirectly through Postabank, but the left-wing Horn Government continued to fund the opposition daily. The articles cover the reasons for the unfavorable peace treaty and blame outgroups such as the Czech politicians Beneš and Masaryk and British historian SetonWatson's ${ }^{11}$ anti-Hungarian propaganda. The reasons given for the unjust peace are that Wilson's points were applied only to the victors, the French dislike of the Hungarians, and the pacifist policies of Károlyi ${ }^{12}$ and Béla Linder. ${ }^{13}$ The articles of Magyar Nemzet evoke the tone of Pesti Hirlap from 1920.

In 2000, the length of text in the right-wing newspaper was double that of 1995 - a total word count of 12,482 words. In 2000, Magyar Nemzet merged with the radical right-wing newspaper Napi Magyarország and was published specifically as a newspaper supporting the Fidesz-MPP ${ }^{14}$ party. Most of the moderate right-wing journalists were replaced by the staff of Napi Magyarország, and a radical perspective characterized the newspaper (Monori 2006). The radical tone appears in the reports on the commemorations of MIÉP, an extreme right-wing party. The daily published a speech by István Csurka given at an assembly entitled Justice for Hungary!, in which Csurka claimed that the Horn Government ${ }^{15}$ was guilty of failing to request the repeal of the Beneš decrees when concluding the Slovak Treaty. There are a large number of articles in this text corpus about the commemorations of Hungarians living abroad.

In 2005, the radical tone did not change, despite the fact that Magyar Nemzet became an opposition newspaper, and the Medgyessy Government withdrew state support. However, the construction of the right-wing media network continued, and Viktor Orbán called on his supporters to subscribe to Magyar

11 Robert William Seaton-Watson (1879-1951): British publicist, historian, and political activist. At the beginning of the twentieth century, many people, typically in Anglo-Saxon and Pan-Slavic circles, considered him one of the most renowned international experts on the Austro-Hungarian Monarchy and South-Eastern Europe. It is probable that he was significantly involved in preparing the Treaty of Trianon, so on the Hungarian side he was considered the grave-digger of historical Hungary.

12 Mihály Károlyi (1875-1955): politician, Prime Minister, first President of the Republic of Hungary. A radical democrat, leader of the bourgeois democratic revolution (October 31, 1918) and the first bourgeois government.

13 Béla Linder (1876-1962): Military officer, Minister of Defense in the Károlyi Government.

14 FIDESZ-MPP: FIDESZ - Alliance of Young Democrats, MPP - Hungarian Civil Party. Rightwing national conservative party. The party had three names: (1) FIDESZ: Alliance of Young Democrats (1988-1995); (2) FIDESZ-MPP (1995-2003); (3) FIDESZ-MPSZ: Hungarian Civic Association (2003-)

15 Horn Government (1994-1998). This was the third government of Hungary after the change of regime, and was formed from a coalition of two parties, MSZP and SZDSZ. 
Nemzet, so the right-wing bond remained. The number of words in the text of 2005 is 10,442 .

In this corpus, events related to the Treaty of Trianon are the movements of extremist groups (Jobbik, Hatvannégy Vármegye Ifjúsági Mozgalom) and the activities of cross-border organizations. One of the demands of the extremist right-wing demonstration in front of the embassies of neighboring states was autonomy for cross-border minorities. Another topic that the demonstrators associated with the Trianon anniversary is the referendum on dual citizenship. Demonstrators, domestic and cross-border commemorators also sharply criticized the Gyurcsány Government. ${ }^{16}$ Journalists also evaluated the past, focusing on the contemporary politics of successor states, especially the Czechs and Romanians.

In 2010, the parliamentary vote on the enactment of National Unity Day as a national day of remembrance was the central issue in the largest right-wing corpus. The delegates of MSZP ${ }^{17}$ voted against the enactment, while LMP abstained. According to László Kövér, ${ }^{18}$ the purpose of the memorial day is to 'start discussing the national trauma caused by the decision 90 years earlier.' MSZP did not attend the parliamentary memorial day on June 4, so all these events deepened the divide between the two political sides. A sarcastic article was published in Magyar Nemzet about the absence of the MSZP. As National Unity Day supports conversation about the trauma, and MSZP did not participate in it, this means that the party does not want to participate in this conversation; i.e. in the healing process. Thus, paradoxically, MSZP contributed to the rightwing expropriation of Trianon.

The longitudinal examination of the intergroup evaluation in the right-wing text corpus showed that in each examined year there are subgroups within the Hungarian group that were in conflict with the ingroup regarding Trianon.

Also in the left-wing text corpus there are some enemy groups within the Hungarian group. These are mostly the opponents of the Social Democrats; these 'mouth-breaking patriots' are the Hungarian ruling class who signed the

16 Gyurcsány Government (2004-2009): The government called a referendum on dual citizenship on December 5, 2004, which ultimately ended in failure because neither the votes in support of nor the proportion of votes reached the $25 \%$ required for validity. On the other hand, the government's campaign against dual citizenship weighed on the long-term relationship between Hungarian politics and Hungarians living abroad.

17 MSZP: Hungarian Socialist Party. Center-left social democratic party in Hungary. This was founded in 1989 from the former members of the state party, the Hungarian Socialist Workers' Party. Between 1994 and 1998 and between 2002 and 2010, it was the ruling party of Hungary.

18 László Kövér (1959-). In 1988 he was a founding member of FIDESZ, and since 2010 he has been the Speaker of Parliament. 
treaty. The pattern of intergroup evaluation in the left-wing text corpus is very similar to that in the right-wing text from 1920 to 2010 (see Figure 6).

Figure 6. Left-wing evaluation, 1920-2010, subject of evaluation: Hungarians (\%)

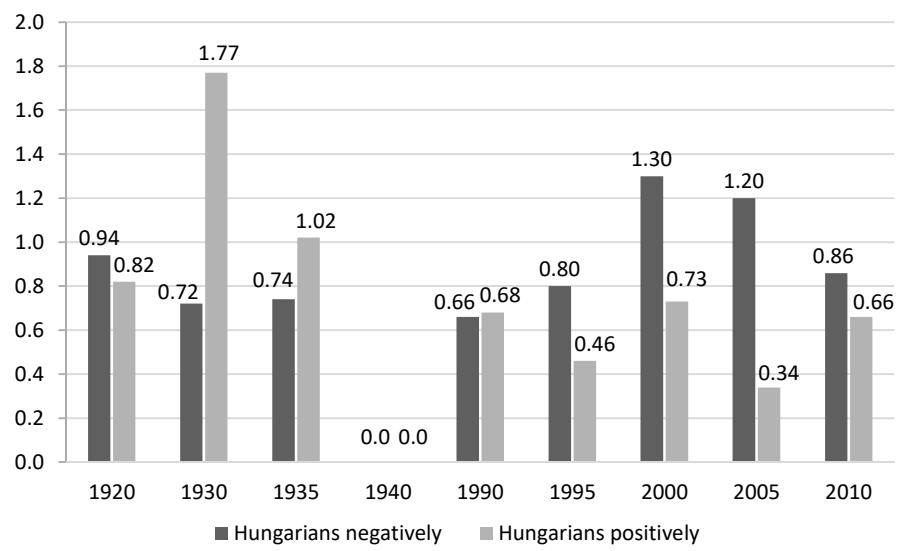

Source: Author's construction

However, between 1920 and 1940 the opposing groups did not organize according to political orientation, but rather by their acceptance or rejection of the treaty. From 1990 onwards, the central theme of Trianon was the search for a scapegoat, and since 2000 both political sides have developed their own version of the issue of responsibility.

Another important result in the longitudinal study is that the events occurring in parallel with the Trianon anniversaries and their social representations in the media texts influence the narrative psychological characteristics in the text corpora. This is because the actors in these present events are also part of the ingroup or the enemy group and their evaluation influences the outcome of the intergroup evaluation. Therefore, in the course of examining the media texts, it would have been more worthwhile to consider only the opinion genres in the intergroup evaluation. However, by introducing the news genres into the research, we gain insight into the fact that current political events which threaten the group identity evoke the chosen trauma of the group. Respectively, the traumatic event, the anniversary of Trianon, evokes the current identity threat to collective memory. 


\section{Trauma elaboration and emotion}

Based on Pennebaker (2001), I presumed that the trauma-induced shock would initially imply an emotionally saturated narrative, but that after time emotions would be replaced by cognitive expressions, which tendency can be observed in personal life events as well as in group events.

Likewise, according to the sixth hypothesis, in the period immediately following the traumatic event, both in the right-wing text and the left-wing text, the traumatic event narrative has strong emotional saturation and low cognitive content.

To examine the frequency of emotional references, I compared the number of words that express all kinds of emotions found in texts to the word count of the right-and left-wing newspapers grouped annually. (I undertook the percentage calculation by dividing the number of emotional words found in the right-wing and the left-wing corps in the given year by the word count of the text multiplied by one hundred).

Figure 7 clearly shows that the relative frequencies of words related to emotions measured in the years immediately following the traumatic event (in 1920 and 1930) are relatively high. Moreover, they were highest in 1930 in the right-wing text corpus, at $1.66 \%$.

Figure 7. Relative frequency of words expressing emotions in left-wing and right-wing newspapers in 1920-2010 (\%)

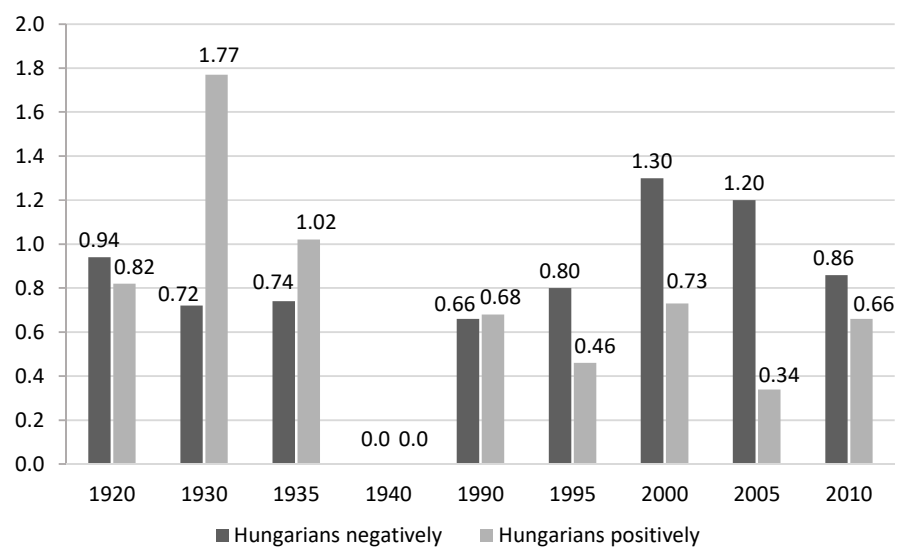

Source: Author's construction based on Fülöp's research in 2012 


\section{Trauma elaboration and negation}

The common use of denials and 'no, no, never'-types of tropes is discernible in the press corpus on Trianon. The first phase of the elaboration of individual traumas and losses (the process of mourning) involves the denial of loss based on the chosen trauma model of Volkan (1998).

According to the seventh hypothesis, the early trauma narratives show a regressive mode of action: this involves primitive countermeasures, such as denial and the projection of negative intentions and feelings.

I examined the proportion of denials per year in the right and left-wing corpora, similarly to the examination of emotions.

Figure 8 clearly shows that the relative frequency of denials is highest in the right-wing text corpus of 1920, but it decreases in 1930; however, then it rises on both political sides and remains relatively high, at between 2 and 3 percent.

Figure 8. Relative frequency of denials in left-wing and right-wing newspapers in 1920-2010(\%)

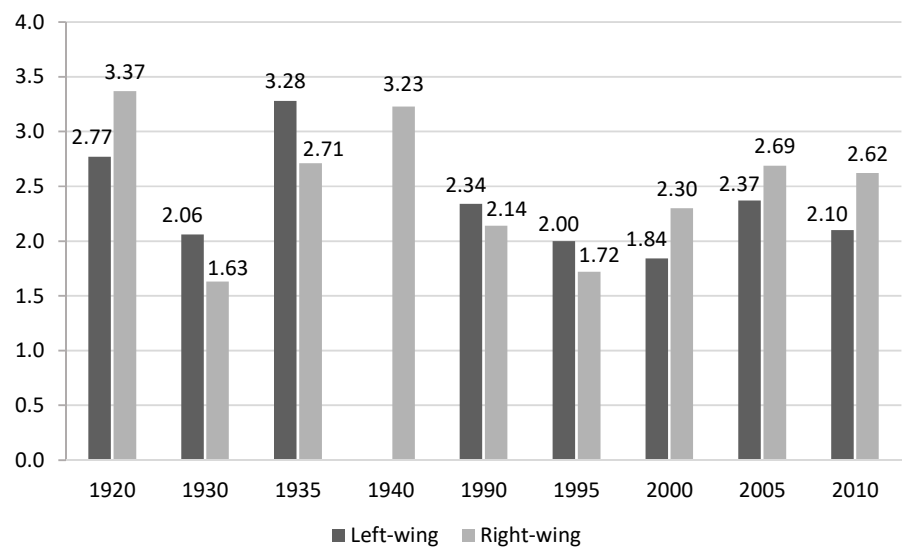

Source: Author's construction based on Hargitai's research in 2005

\section{DISCUSSION}

The results reveal that the nationwide traumatic nature of Trianon appears in the media texts, too. In the period of the historical trauma, politicians, witnesses, contemporaries, and those who experienced the loss, the characters of 
communicative memory, speak. In the media texts on the treaty, the expression of collective emotions and denial of the loss, as well as the high self-esteem of the ingroup and the devaluation of the outgroup are characteristic of Hungarians, which indicates an identity threat. In the 1930s and 1940s, this trend does not decrease, either in the right- or left-wing media texts. A strong downward trend in denials cannot be detected either. Contrary to the eighth hypothesis, in reference to which I assumed that the relative frequency of collective emotions and denials would be high in the first stage of trauma processing and decrease with time, it did not decrease on either political side. In fact, the downward trend is only discernible in the positive evaluation of the ingroup in the media texts after the political changes of 1990. But meanwhile, the negative evaluations of ingroup are greater than positive evaluations, both on the right and the left after 1990, and show no declining trend as the years progress. At the same time, the negative evaluations of the external group are also high. This trend contradicts Hypothesis 5 about intergroup evaluation and trauma evaluation, as in fact both positive and negative evaluations should decrease over time for both the ingroup the outgroup. The predominance of negative evaluations of the ingroup after 1990 implies a special so-called scapegoat narrative. These texts refer to seeking, on both political sides, those responsible for the Treaty of Trianon within their own group. Thus, the predominance of negative evaluations in the case of the ingroup can be understood.

But the continuous presence of collective emotions and denial, as well as the negative evaluations attributed to the outgroup and the ingroup in both the rightand left-wing texts, indicate a lack of advance in trauma elaboration.

\section{CONCLUSION}

Trianon trauma, viewed in relation to the occurrence of the traumatic event until 2010, based on Volkan's scenario of chosen trauma, can now be depicted as follows:

In the texts of the 1920s, narrative psychological references to anger and denial are signs of sudden shock. Demonstrations are organized against the treaty, which are backed by the government and organizations close to the government.

In 1930, these rituals are repeated on the anniversary of the event (most newspaper articles render the account that life stops for five minutes, just as in 1920, and the associations representing the revision involve commemoration); that is, the purpose of the repetition is to strengthen the identity of the group, which is based on a common grievance, and whose keystone is legitimate 
reparation - that is, revision.

In fact, the latter repeat protests that deny rather than accept the treaty. Many of the texts of the 1930s speak about nothing but the commemoration of irredentist organizations, which almost encompass the whole world and involve sending memoranda to the League of Nations giving voice to their claims. It is easy to see that revision, which is the same as irredentism in public opinion, did not stimulate the national group in the direction of reconciliation with the lost object (in this case, lost territories). Indeed, an article from 1940 after the partial restoration of the pre-Trianon borders is hopefully triumphant rather than mournful, as Pesti Hirlap writes:

By the twentieth anniversary of signing the Treaty of Trianon, some of the borders of Trianon have already collapsed, and two parts of the country have returned happily to the bosom of the mainland. We hope that the anniversary when the entire border will only be a memory and all the injustices and stupidity of the Trianon Treaty will vanish is not far away. (Pesti Hirlap, June 4, 1940)

Historiography taught us that the triumph did not last long, as the Paris Peace Treaty of 1947 essentially restored the Trianon borders. Since the Soviet leadership, together with the Allied powers, also played an important role in determining the conditions of the Paris Peace Treaty, Hungarian politicians completely abandoned their revisionist aspirations after the Second World War.

Trianon became righteous in Hungarian propaganda, in official historiography, in newspapers columns, and in history books. The nationalities revolted against the 'prison of folks' - that is, against the Monarchy, so according to the official attitude, the aspirations of the Romanians and the Czechs of becoming independent were merely justified and sanctioned by the treaty. The hopes of Hungarians remained with Lenin only, who, declared the whole procedure a robbery. But Lenin was buried a long time ago. (Ormos 1990:2)

This Trianon narrative dominated the years of socialism until the 1980s, and research on the topic was banned, and an even deeper silence surrounded the situation and fate of the Hungarians living in neighboring countries. (Ormos 1990:2)

Among the newspapers I examined, Magyarság, Pesti Hirlap, Népszava, and Új Nemzedék existed until 1944, and of these, Trianon was only commemorated in Pesti Hírlap in 1940. In 1945, only Népszava resumed from these newspapers 
(on February 2), but I did not find any texts about Trianon around June 4, either in the 1945 issue or later, until 1990. Magyar Nemzet was started in 1938 under the editorship of Sándor Pethő, who left Magyarság, and was permitted to appear until 1944, but I did not examine it regarding this period. While the newspaper resumed publication on May 1, 1945, and it is still published today, I found no articles about the Trianon anniversary in it during the period of socialism. The third newspaper examined after the change of regime was Népszabadság, whose predecessor was Szabad Nép, published since 1942. Népszabadág was first published under this name on November 2, 1956; however, neither Szabad Nép nor Népszabadság write about Trianon around the time of the anniversary until 1990.

This means that the newspaper texts I have examined longitudinally tell the story of a drama whose outcome is actually not really considered tragic between 1920 and 1940. Thus there is no material in my research about the really tragic ending, the conclusion of the Second World War.

Despite the fact that at the conclusion of the Second World War the Paris Peace Treaty (1947) meant nearly the same loss of territory as occurred after the First World War, almost fifty years of silence followed the claim that Trianon led to the Second World War. In contemporary texts, this claim is constantly displayed in a context in which the parties dictating the peace are the perpetrators, and the Hungarians are the victims. As we can read in Pesti Hírlap in 1940:

However, the dictators of peace around Paris were not driven by insight, but blinded by hate bringing to the negotiating table the glowing hatred of the war-torn masses. Instead of wisdom, bias and draconian austerity dictated these contracts. There could be nothing else, but hatred, another despair, another war. Those who were pureeyed had already seen this, - Clemenceau, the evil spirit of the peace conference, immediately cynically noted that their work had sown the seeds of a new war. (Pesti Hirlap, June 4, 1940)

After the political changes of 1990, this explanation returned and it is now very easy to draw a parallel between the two treaties, for the perpetrators are the same and the loss is also similar. Thus, it is not only the traumatic event that is repeated in the picture of the Paris Peace Treaty, but also the mental representations associated with that event. We can say that this sacrificial narrative is in circulation even today. 
Obviously, in the period I call latent there were references to Trianon, ${ }^{19}$ if not always around the anniversary, but to prove this statement requires more thorough research.

In aggregate, I used narrative psychological content analysis in my research to support Volkan's chosen trauma concept when examining post-1990 and contemporary newspapers. The hypotheses related to the trauma-processing indicators of narrative psychology were not always confirmed in the longitudinal examination of the full text corpus, indicating that the Trianon trauma is not heading towards elaboration, but rather acts as a trauma that is chosen for its effect on current political events and political forces.

\section{REFERENCES}

Bigazzi, S. - I. Csertő - A. Nencini (2006) A személy- és csoportközi értékelés pszicho-lingvisztikája. Magyar Számítógépes Nyelvészeti Konferencia (4.), Szeged, pp. 267-276.

Buzinkay, Géza (2016) A magyar sajtó és újságirás története a kezdetektöl a rendszerváltásig. Budapest, Wolters Kluwer Kft.

Csertő, I. - J. László (2016) A csoportközi értékelés, mint a csoporttrauma érzelmi indikátora a nemzeti történelem elbeszéléseiben. In: Sepsi, E. - K. Deres A. Czeglédy - Cs. Szummer (eds.): Studia Caroliensia: Nyelv, Kultúra, Identitás: A Károli Gáspár Református Egyetem 2015-ös évkönyve. Budapest, L'Harmattan and Károli Gáspár Református Egyetem, pp. 305-331. Dénes, I. Z. (2008) Liberalizmusok és nacionalizmusok. Magyar Tudomány, No. 2008/01, p. 5.

Fülöp, É. (2010) A történelmi pálya és a nemzeti identitás érzelmi szervezödése. PhD-értekezés. Pécsi Tudományi Egyetem - BTK BTK Pszichológia Doktori Iskola

Fülöp, É. - B. Ilg - I. Csertő - Zs. Szabó - B. Slugoski - J. László (2012) Emotion elaboration of collective traumas in historical narratives. http:// www.sydneysymposium.unsw.edu.au/2012/chapters/FulopEASP2012.pdf

Gyáni, G. (2010) Az elveszithető múlt. Budapest, Nyitott Mühely

19 "However, little by little, the Hungarian intellectuals found a way to start talking about Trianon by avoiding the word Trianon. They collected more and more materials and wrote more and more articles, essays and books that indirectly referred to Trianon. Then, at the beginning of the $1980 \mathrm{~s}$ even the word 'Trianon' also appeared." (Ormos 1990) 
Habermas, J. (1993) A társadalmi nyilvánosság szerkezetváltozása. Vizsgálódások a polgári társadalom egy kategóriájával kapcsolatban. Budapest, Századvég

Hargitai, R. - M. Naszódi - B. Kis - L. Nagy - A. Bóna - J. László (2005) A depresszív dinamika nyelvi jegyei az én-elbeszélésekben. A LASvertikum tagadás és a szelf-referencia modulja. Pszichológia, Vol. 25, No. 2., pp. 181-199.

Klestenitz, T. (2013) A katolikus sajtómozgalom Magyarországon 1896-1932. Budapest, Complex

Klestenitz, T. (2018) Katolikus sajtó és nyilvánosság a második világháború éveiben. In: Útkeresés két korszak határán. Agyagosszergény, Közi Horváth József Népföiskola, pp. 39-52. http://real.mtak.hu/122715/1/KlestenitzTibor_ kesz0818.pdf

Kovács, É. (2015) Trianon, avagy a „traumatikus fordulat” a magyar történetírásban. Korall: Társadalomtörténeti Folyóirat, No. 59., pp. 82-107.

Körösényi, A. - Cs. Tóth - G. Török (2007) A magyar politikai rendszer. Budapest, Osiris Kiadó

László, J. (2005) A történetek tudománya. Bevezetés a narratív pszichológiába. Budapest, Új Mandátum

László, J. (2012) Történelemtörténetek. Budapest, Akadémiai Kiadó

Litván, Gy. (1984) A Világ 1910-1926. In: Czére, Gy. (ed.): Világ Repertórium. I. köt. 1910-1912. A PIM bibliográfiai füzetei. Napilapok repertóriumai. Budapest, Petőfi Irodalmi Múzeum, p. 412.

Monori, Á. (2006) Médiaháborúk. In: Bajomi-Lázár, P. (ed.): Magyar médiatörténet a Késö-Kádár kortól az ezredfordulóig. Budapest, Akadémia Kiadó, pp. 259-290.

Ormos, M. (1990) Elhallgatások nélkül. Magyar Nemzet, June 4, 1990.

Pennebaker, J. W. (2001[1993]) A stressz szavakba öntése: egészségi, nyelvészeti és terápiás implikációk. In: László, J. - B. Thomka (eds.): Narratívák 5. Narratív Pszichológia. Budapest, Kijárat Kiadó, pp. 189-205.

Ricoeur, P. (2006) Memory, History, Forgetting. Chicago, Chicago University Press Romsics, I. (2001) Magyarország története a 20. században. Budapest, Osiris Kiadó Sipos, B. (2011a) Sajtó és hatalom a Horthy-korszakban. Budapest, Argumentum Kiadó

Sipos, B. (2011b) Rákosi Jenő: Emlékezések. http://www.irodalomismeret.hu/ files/2011_3/sipos_balazs.pdf [Last access: 0111 2020]

Szabó, M. (2015) Az újkonzervativizmus és a jobboldali radikalizmus története: 1867-1918. Budapest, Új Mandátum

Török, G. (2005) A politikai napirend: politika, média, közvélemény. Budapest, Akadémiai Kiadó 
Volkan, V. D. (1998) Bloodlines: From Ethnic Pride to Ethnic Terrorism. New York, Farrar, Straus and Giroux Inc.

Volkan, V. D. (2007) Massive trauma: The political ideology of entitlement and violence, Revue française de psychanalyse, Vol. 71, No. 4., pp. 1047-1059; https://doi.org/10.3917/rfp.714.1047

Zeidler, M. (2009) A reviziós gondolat. Pozsony, Kalligram

\section{APPENDIX: HISTORY OF RELEVANT NEWSPAPERS FROM THE BEGINNING TO 1944}

\section{Népszava and the Hungarian Social Democratic Party (1873-)}

When Népszava started (1873), it was a newspaper of the labor movement, edited by Jakab Meyer (Viktor Külföldi), published weekly in German and Hungarian. It officially became the newspaper of the Hungarian Social Democratic Party in 1880, and a daily newspaper in 1905. At the turn of the century, the party's main aspirations included the struggle for a civil, European Hungary, the introduction of universal and secret suffrage, the satisfaction of the social needs of workers, and the fight against violent Hungarianization. Népszava at first opposed the war, with a full-page headline appearing in its July 26, 1914 issue entitled "We Don't Want a War!" By the autumn, however, it had already accepted the government's argument about the inevitability of war, shifted responsibility to the enemy, and encouraged workers to fight. During the four years of the war, it mainly reported on war fronts, and despite censorship, it also managed to report on most of the antiwar Social Democratic movements. At the time of the October Revolution, Népszava was close to the government, demanding a just peace and the autonomy of Hungarian nationalities. During the Council Republic, Népszava was the official morning paper of the Hungarian Socialist Party, the number one pro-government daily. After the fall of the Council Republic, Népszava again became the newspaper of the Social Democratic Party, and its editorin-chief was Béla Somogyi, who published articles with his colleagues about the atrocities of the Counter Revolution. In the second half of 1919, after the victory of the Counter Revolution, the Social Democratic Party re-formed and became a mass party with 14,000 party members and 200,000 union members, its own cultural, sports, and leisure associations, and its own press. At that time, the party demanded an end to the aggression of the Counter Revolution, the suppression of anti-Semitism, and general and secret elections. The Social 
Democratic Party took part in a coalition government led by Károly Huszár, also recognized by the Entente powers, the latter who wished to run in the January 1920 parliamentary elections. However, many candidates were prosecuted for their role in the Council Republic, and authorities detained or insulted them, and the party withdrew from the coalition government and did not run in the elections. Thus, when the Treaty of Trianon was signed, the Social Democratic Party supported the signing of the peace and demanded a peaceful revision, referring to the right of peoples to self-determination and the friendship of peoples living side by side - these demands also appeared in Népszava.

\section{Pesti Hírlap (Pest Newspaper) (1879-1944)}

Pesti Hirlap started on January 1, 1879 as the daily newspaper of the Légrády Brothers Book and Newspaper Publishing Company. It was loyal to the contemporary government of Kálmán Tisza. Its purpose was to serve and satisfy the needs of the audience, but in addition, the owner, Károly Légrády, wanted to dictate the content of the newspaper. A business focus dominated the newspaper, which resulted in a large number of ads. The paper provided up-todate news by many means, building its own network of correspondents both abroad and at home. At the turn of the twentieth century, Pesti Hirlap became a popular daily newspaper for liberal metropolitan citizens and was removed from party politics (Buzinkay 2016).

After the loss of the First World War, the journalists of Pesti Hirlap first raised the idea of a national independent kingdom, then during the October Revolution they sided with the civilian government for a short time, but their dislike of the workers and the Communists was undisguised.

Pesti Hirlap was banned during the Council Republic in May 1919, along with other civilian dailies. When the daily was able to reappear (on September $28,1919)$, it supported the Horthy regime and reported with satisfaction on the executions of the Communists, and associated retaliation. The Trianon peace treaty was called the "paper rag" by Pesti Hirlap. In the weeks leading up to the signing of the peace treaty, it argued against the signing. In the 1920s, Pesti Hirlap was in the service of revision, reporting even the slightest irredentist movement. It also spread strong revisionist propaganda abroad, publishing issues in French, Italian, and English protesting against the peace in the 1920s and 1930s. The Lord Rothermere campaign also received the most publicity in its pages.

On June 21, 1927, English newspaper magnate Lord Rothermere published an article in the Daily Mail entitled Hungary's Place in the Sun - Safety for 
Central Europe. Rothermere argued for the return of the Hungarian-inhabited areas along the border. This article was published in full translation in the next day's issue of Pesti Hírlap, and was commented on by editor-journalist Jenő Rákosi. The impact of the events of The Revision League (July 27, 1927) that was formed in Hungary brought together advocacy economic organizations. From then on, the Revision League and its president, Ferenc Herczeg used Pesti Hirlap as a mouthpiece. The issue of revision remained a central topic in the newspaper in the 1930s, while during the reign of Gyula Gömbös (1932-1936) the newspaper supported the head of the government's foreign policy efforts at revision, the alliance with the Italians and Germans, and Hitler's appointment as German Chancellor.

Thanks to the two Vienna Awards, the Pesti Hirlap could enthusiastically celebrate the return of a part of Slovakia in 1938 and the return of north Transylvania in 1939, and considered the Rothermere initiative and its own efforts to have played a part in this. Pesti Hirlap reported with confidence on World War II, which increasingly seemed to have been lost. At the end of the war, in March 1944, the Germans occupied Hungary and power was taken over by the pro-German Sztójay Government, which sought to oust anti-German forces from public life, arresting many members of the civil opposition and dissolving opposition parties. One-hundred-and-fifty magazines and 18 Budapest and rural dailies were banned. Pesti Hirlap did not cease to exist, but most of its employees were forced out of work. In the summer months of 1944, war coverage covered the front pages of the Pesti Hirlap, while in October the newspaper headline greeted the Hungarian Nazi Government of Ferenc Szálasi, who had come to power with German help. German and Hungarian fascist troops occupied strategic points in the capital on October 15, and in the evening Szálasi announced the takeover and the resumption of the war. Thus, from November onwards the propaganda in the Pesti Hirlap urged the defense of the capital against the Red Army. Finally, a government decree published in December 1944 suspended most of Budapest's dailies. After 1945, Pesti Hirlap reappeared under the title Hírlap, while the owner of the newspaper was still the Légrády Brothers Limited Liability Company. However, in August 1949, Pesti Hirlap was finally closed down.

\section{Budapesti Hírlap (Budapest Newspaper) (1881-1938)}

This publication started on June 16, 1881, edited by József Csukássy. Most of the staff consisted of journalists who had been fired from Pesti Hirlap who did not agree with the influence of the owner of Pesti Hírlap, Károly Légrády, about 
the content of the paper. Jenő Rákosi, who was the co-owner and editor-in-chief of the paper, became the sole owner in 1891. Rákosi built the headquarters of Budapesti Hirlap, where the publishing office, the editorial office and its own printing house operated. The spirit of the newspaper was basically determined by the political views of Jenö Rákosi, who supported all movements that supported the Hungarians. Rákosi was convinced that the nationalities living in Hungary could and should be assimilated into Hungarian society, and he opposed all attempts at Germanization. The claim to the conservatism of the Budapesti Hirlap is supported by its position on the Church Policy Act, as it opposed civil marriage. This mostly reflected the opinion of Count Albert Apponyi, the conservative politician. Until 1905, Budapesti Hirlap was an opposition paper, which opposed the Liberal Party and the Government of Kálmán Tisza. The Budapesti Hirlap played a major role in the 1905 victory of the conservative opposition. From 1910 onwards, Rákosi supported the policy of Prime Minister István Tisza, as both considered certain financial and educational guarantees essential for the extension of universal and secret suffrage. Budapesti Hirlap also agreed with István Tisza's war aspirations, based on the principle of one state, one nation, so it welcomed the outbreak of war. The Budapesti Hirlap was banned during the Council Republic, and Jenö Rákosi was arrested. The daily reappeared on September 28, 1919 during the Counter-Revolution. The signing of the Treaty of Trianon was opposed by the Budapesti Hirlap. In the Horthy era, Rákosi did not fully support the system, speaking out against the terror in Budapest and the countryside. After Rákosi's internal struggles, he left the paper on January 6, 1925, and became a journalist for Pesti Hirlap. With Rákosi's exit, the Budapesti Hirlap steadily declined in popularity. The Budapesti Hirlap closed in 1938.

\section{Az Est (The Evening) (1910-1939)}

Az Est was first published on the afternoon of April 15, 1910. It was founded by Andor Miklós, who previously wrote a column on economics for the daily Pesti Napló. Az Est is often considered a tabloid, but it was not one. It was an American-style political daily that took advantage of the business opportunities available to the press, employed sensationalism, and gave ads a particularly prominent place. It was a liberal daily newspaper, at most temporarily committed to any political direction or politician. It was characterized by an ambivalent attitude toward the horrors of the Counter Revolution, fighting, anarchy, and atrocities, but supporting Horthy and the National Army in their evasion. The daily later supported the Government of István Bethlen. Az Est argued for the 
signing of the peace treaty, but considered the peace to be temporary. In the 1920s, Est newspapers (three dailies) moderately criticized the government (Bethlen), condemned anti-Semitic jokes, and the university numerus clausus, but considered the expulsion of Galician Jews from the country to be appropriate. With the death of Andor Miklós in 1933, concern with the press also began to decline, leaving the ownership of the company in the hands of his wife, while the editor-in-chief became Imre Salusinszky. With the coming to power of Gyula Gömbös, the pages of the liberal press were allowed to prevail less and less, and as a result of the shift in politics to the right, the editorial board also changed. With the enactment of the first and then the second Jewish law, journalists of Jewish descent were also fired from the editorial office of Az Est. In the summer of 1939, the increasingly threatening war was the subject, with the daily supporting Mussolini's policy. Eventually, the Est Publishing Company was nationalized, and $A z$ Est was last published on November 17, 1939.

\section{Világ (World) (1910-1926)}

The strengthening radical civil democratic position of 1905/1906 did not have its own daily newspaper. There was a need for such civil radicalism with its own program to have its own newspaper, so the Masonic daily Világ was launched on March 30, 1910. An extensive network of Masonic lodges operated in Hungary at the turn of the century but the Freemasons had their own internal documents. Eventually, Világ was financed by the Eötvös Lodge and published by Dr. Lajos Bálint. The launch of Világ was definitely a success, with the number of copies soon growing to ten thousand, while its readership consisted of the educated strata of the city's progressive intellectuals and bourgeoisie. In 1913, an editorial change took place, and under the leadership of Lajos Purjesz the newspaper adopted a more radical tone. After the formation of the Civil Radical Party in 1914, Világ became the party's paper and thereafter officially represented a radical program. The party's program was formulated by Oszkár Jászi: he spoke of a radical policy of independence that would create economic independence from the monarchy and local governments, in addition to public education reform, the secularization of church property, freedom of thought and the press, freedom of assembly, and avoidance of Hungarianizing minorities.

In the summer of 1914, most of the dailies were pro-war, but the Világ was one of the few exceptions, although at first it was not consistent enough on this issue (Litván 1984). From 1917 onwards, Világ fully supported the formation of a democratic national unity front under Károlyi's leadership. This alliance served as the basis for the National Council formed in October 1918, and then 
for the Károlyi Government. Later, members of the Civil Radical Party also took part in Károlyi's Government. The opposition Világ became a pro-government newspaper after the bourgeois revolution (October 31, 1918), representing the government's middle-class policy. The newspaper had declined in popularity by early 1919, fueled by the disintegration of the governing coalition and the Radical Party's decision not to run in the April elections but rather to support Social Democratic Party candidates. Elections did not take place after that, because the Berinkey Government resigned on March 20, 1919, and the Social Democrats agreed with the communists to take power and introduce a proletarian dictatorship without Károlyi's knowledge. The Social Democrat leaders Sándor Garbai and the communist leader Béla Kun proclaimed the Council Republic.

As a result of the events, the Civil Radical Party disbanded itself on March 22. Világ was still published under the name Fáklya (Torch) during the five months of the proletarian dictatorship, and had a focus on public-educationrelated issues.

At the time of the Counter Revolution, Világ was published on September 28, 1919 , but struck a much more moderate tone. The freedom of the press was formally restricted by a return to the liberal but non-democratic press law of 1914, which was further tightened in the 1920s. Thus, the reintroduction of censorship and the regulation of paper distribution also hit the Világ. Most of the daily's old main staff and editors (Jászi, Bíró, Szende, Bölöni) were forced to emigrate.

Világ's sixteen-year existence was finally ended by the franc counterfeiting scandal. The scandal erupted in Hungary in 1925 when it emerged that rightwing circles wanted to take revenge on the Trianon peace treaty by producing and distributing fake thousand-franc notes in France - a move that would also have financed revisionist propaganda. This French franc counterfeiting took place at the Cartography Institute in Budapest, which was part of the Ministry of Defense. Thus, not only the perpetrators and their helpers, but also politicians from higher circles such as Pál Teleki and István Bethlen were subjects of suspicion. Világ also admitted the complicity of the National Bank in the Franc-counterfeiting affair. The radical right demanded a ban on the paper, which eventually occurred on May 1 . The interior minister banned the paper indefinitely - that is, permanently.

\section{Új Nemzedék (New Generation) (1913-1944)}

Új Nemzedék was first published in 1913 as a weekly political journal, edited by right-wing journalist István Milotay. Members of the paper's editorial staff 
were initially radical pro-independence advocates. The magazine was militantly anti-war and from the beginning it was opposed to an alliance with the Germans (Szabó 2015)

However, the tone of the Új Nemzedék became more and more radical as a result of the events of 1916-17 (the Romanian invasion of Transylvania and the fall of the Tisza Government). Moreover, the newspaper's new ally became aristocratic great capital, which, for all its flaws, was considered to be much more the bearer of national values than Jewish great capital. The change of attitude of Milotay and his co-editors was most pronounced during 1917-18, when Milotay began to approach the group most strongly associated with right-wing radicalism - the circle of Béla Bangha. The Bangha group eventually took the first steps towards launching Christian newspapers, but Új Nemzedék was also involved in the propaganda battle for an independent Christian press. Új Nemzedék was finally purchased in December 1918 by the Central Press Company (KSV).

The Central Press Company was founded as a joint stock company by Jesuit Pope Béla Bangha and his supporters. His goal was to create a self-run publishing unit, with its own newspapers, capable of addressing the masses, as opposed to the mass press responsible for disrupting traditional values. Newspapers that built on disseminating rapid, up-to-date news and entertainment, such as Az Est, did not discourage the audience with their preaching.

Both the Central Press Company and Új Nemzedék were banned under the proletarian dictatorship. When the papers were relaunched on September 28, 1919, the Új Nemzedék was one of the most important dailies of the Central Press Company, edited by Milotay again. Initially, the newspapers of the Central Press Company were also dominated by petty-bourgeois, Christian socialist elements, and the unity of Christianity against the destructive dailies was demonstrated. A popular column in Ujj Nemzedék was the "Pardon" column, edited and written by Dezső Kosztolányi, a respected writer of the age. In the column, journalists favored the new system, which condemned the revolutions, the Social Democrats, the bourgeois radicals and the Communists. Jews and Freemasons were held responsible for the Red Terror and denied the White Terror.

In November 1920, Milotay left Új Nemzedék and was replaced by two more radical journalists, Lehel Kádár and István Lendvai. The fight against the destructive press continued even more strongly, with KSV journalists demanding state control of the press and the establishment of a chamber of journalists. Új Nemzedék was most vehemently opposed to the signing of the Trianon Peace. István Friedrich's speech against the signing of the peace and the Entente was published in full by the newspaper. Later, during the years of the Bethlen Government, Új Nemzedék served as the government's right-wing 
opposition, but pursued a loyal opposition policy. The first step was a change of editor on October 1, 1921, when the new editor-in-chief became the liberalCatholic László Szabó. Szabó removed the radical Kádár and Lendvay from the paper. The KSV papers returned to proclaiming Christian-national unity, which was fully in line with government policy (Klestenitz 2013:517). By the mid-twenties, Új Nemzedék and KSV newspapers in general had declined in popularity due to the unsatisfactory financial situation of the publisher, the fierce competition for an audience, and the latter's declining purchasing power. By 1925, Új Nemzedék was being published in 18-19 thousand copies a day, and KSV was struggling with enormous financial problems. Eventually the state rushed to help with a loan, sparking displeasure among conservative Catholic circles. While during the reign of István Bethlen (1921-1931) the synthesis of religiosity and nationalism was the ideological basis of politics, Gyula Gömbös (1932-1936) sought to suppress the influence of the church and wanted to hand over the task of national education exclusively to the state. The high priests realized that the realization of Gömbös' program would lead to the disintegration of the Catholic unification system in the long term, so they sought to strengthen the institutional system. Therefore, in the 1930s, the main goal of the Catholic press movement became to establish the independence of Catholic newspapers (Klestenitz 2013:612-617).

The outbreak and antecedents of World War II in the late 1930s also marked a turning point in journalism. The first Jewish law, passed in 1938, made the setting up of a Press Chamber obligatory, so journalism became strongly regulated in Hungary (the Press Chamber selected journalists on racial, religious, and political grounds). In 1938, about four hundred papers were discontinued for political reasons. At the outbreak of World War II, the Government of Pál Teleki introduced compulsory press censorship. The press increasingly became a tool of foreign policy (Klestenitz 2018:2). The KSV papers, including Új Nemzedék, were committed in many directions, including to the high priesthood, the Christian party, the legitimists, and the government of the time, but they were consistent in two things: they opposed the spread of German National Socialism and Hungarian far-right agitation. The KSV's newspapers were last published on December 16, 1944 (Klestenitz 2018:19).

\section{Magyarság (1920-1944)}

After leaving Új Nemzedék, István Milotay, with Sándor Pethö, started the daily newspaper Magyarság in December 1920 on behalf of the leader of the moderate legitimate opposition, Gyula Andrássy Jr. The paper soon became the 
right-wing opposition to the Bethlen Government and enjoyed the support of the middle classes.

The newspaper attacked liberal values in every forum, its biggest target being Klebelsberg Kuno, a Minister of Culture who was too liberal, according to Milotay. The Magyarság were anti-communist and anti-liberal, and had wellknown journalists: Sándor Pethő, János Komáromi, Jenő Miklós, Jenő Gagyi, András Dékány, János Makkai, György Oláh, Endre Radnai, and Ella Megyery (Buzinkay 2016:1325).

Magyarság went into crisis in the 1930s, and in early 1934 the owner, Olivér Rupprecht Jr., took over the responsibility of editing the paper. Milotay left the paper in 1934 with 16 colleagues and founded Új Magyarság, which supported radical right-wing politics. Sándor Pethő thus became the editor-in-chief of Magyarság, and Gyula Hegedüs the responsible editor.

The newspaper then turned against the policies of the Gömbös Government and represented moderately liberal legitimist views, taking a foreign policy direction against Nazis and the Soviet Union until 1938, when Sándor Pethő was replaced. Kálmán Hubay became the editor-in-chief of Magyarság and thus the paper became an important press body in support of National Socialism, an important German news center, and a distributor of Nazi German money (Buzinkay 2016:1328). It then became the mouthpiece of Nazi movements - first the Szálasi movement obtained the paper until 1941, then it became the forum of another Hungarian Nazi movement until December 16, 1944. 
